\title{
潜水機による局所海底地形図作成および パスプラニング
}

\author{
正員 荒 牧 浩 二* 正員 浦環** \\ Local Map Drawing and Path-Planning for Submersible Vehicles
}

by Koji Aramaki, Member Tamaki Ura, Member

\begin{abstract}
Summary
This paper introduces a system to draw a local map based on range data which are measured by ultrasonic sensors on a submersible vehicle. Topography is represented as the depth values at two-dimensional square cells. Measured depth values and their weights to represent their certainty at each cell are accumulated as the information about the obstacle occupancy and emptiness. The depth of seabed is conjectured with these values, or judged "unknown" when the amount of information is not sufficient.

The features of the system are as follows: 1) Topography is conjectured by combining a large number of sensor readings from multiple positions although each reading has uncertainty of the point where the ultrasonic wave is reflected. 2) The system offers the amount of information which represents the index of reliability of that depth value. 3) The maximum depth for the vehicle to work safely is available when the depth of the seabed has not been conjectured. 4) The path-plan is generated to survey the target area, which is more efficient than a prescribed path-plan such as simply tracing the orthogonal lines.

Experiments at a testing pool and simulations on workstations demonstrate that the proposed system is significantly advantageous for detailed local mapping by a submersible vehicle.
\end{abstract}

\section{1. 緒}

言

有索無索を問わず潜水機は, 海中活動において重要な役 割を担うものとして期待されている。熱水噴出や遺失物を 発見するためなどといった目的のため, 潜水機は海底のす ぐ近くを航行する場合が多くある(Fig. 1 参照)。海底の近 くで安全に活動するためには, 周井の環境, 特に幾何学的 な特徴に基づいたパスプランを生成することが必要であ る。

潜水機による探査活動に先立ちオペレータから与えられ る地形図は, 通常は情報量が不足し精度が充分になく, 予 め詳細なパスプランを設定できない。そのため, 探査活動

* 東京大学大学院工学系研究科

** 東京大学生産技術研究所

原稿受理 平成 7 年 1 月 10 日 春季講演会において講演, 平成 7 年 5 月 17,18 日
中に潜水機自身によって計測される測距データに基づい て, その地形図を逐次更新していく必要がある。すなわち, 適切なパスを計画するためには正確な地形図が必要であ り，正確な地形図を作成するためには，適切なパスプラン が必要とされる。このことから, 潜水機自身による自動的 な局所海底地形図作成と, 未知の領域を隇少させるための パスプラニングは, 相互作用関係にあるといえ, 双方とも

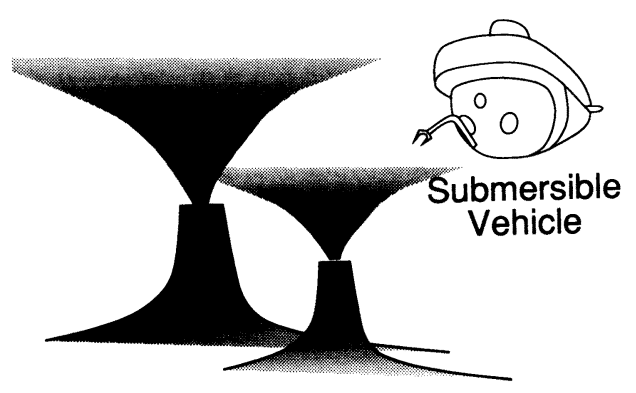

Fig. 1 Finding hydrothermal vents 


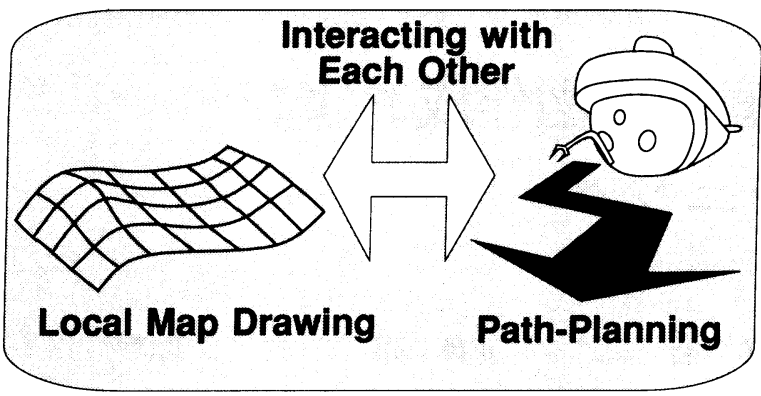

Fig. 2 Essential two elements of submersible activities

海底近くに於ける潜水機の活動に必要不可欠な要素となる (Fig. 2 参照)。

これら 2 つの要素が調和した自動的な局所的地形図作成 システムを形成するために, 本論では以下の 2 つのアルゴ リズムを導入する：

（1）潜水機に搭載された超音波センサから得られ誤差 を含んでいる測距データに基づいて, 周囲の地形図 を作成するアルゴリズム。

（2）完全ではない地図上の与えられた未知の海域を探 査する，パスプラニングのアルゴリズム。 次に,各アルゴリズムのパラメータを実験によって決定し, それらを用いて数值シミュレーションにより提案する手法 の妥当性を示す。

なお, 本論では, 潜水機の位置 $(x, y, z)$ は LBL (Long Base-Line Acoustic System)や, SSBL(Super Short Base-Line Acoustic System)などの測位システムによっ て逐次决定され，潜水機に提供されていることを前提とす る。また, 超音波を反射する物という観点から, 天然の海 底面と人工的な海中構造物の双方をまとめて，障害物ある いは海底と呼ぶ。さらに, 海底にオーバーハングはないも のとする。

\section{2. 地形図の作成}

\section{1 反射点の不確定性}

どのような超音波測距装置であっても，個々の測距值か らは超音波の反射点を指向角の範囲内でしか特定すること ができない(Fig. 3 参照)。指向角は装置の性能に依存する が, 例えば $1^{\circ} \sim 15^{\circ}$ と広く, 離れた地点から正確な地形 図を得るためには, 複数の位置からの数多くの計測值を組 み合わせることによって確率的に推測する必要がある (Fig. 4 参照)。Elfes ${ }^{1), 2)}$ は, 平面に配置した格子点における 障害物の有無の確率を測距センサのデータによって逐次更 新することによって, 陸上用自立型ビークルのための 2 次 元的な地図を作成する手法を提案したが, 本論ではその手 法を基にして, 各格子点における海底深度を決定するアル

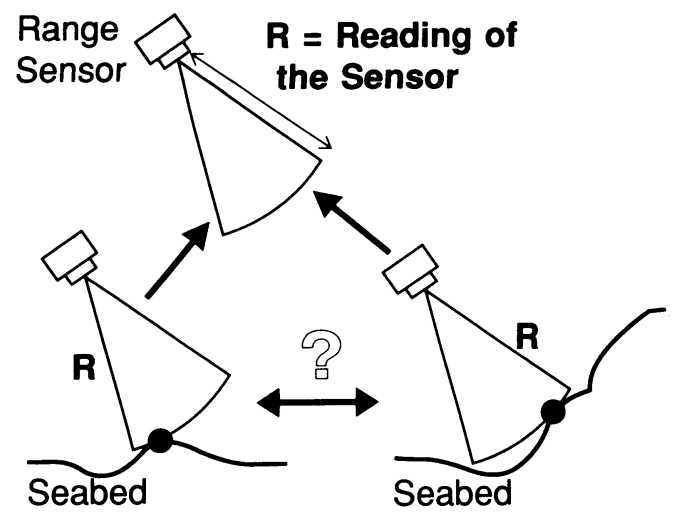

Fig. 3 Uncertainty of the reflecting point

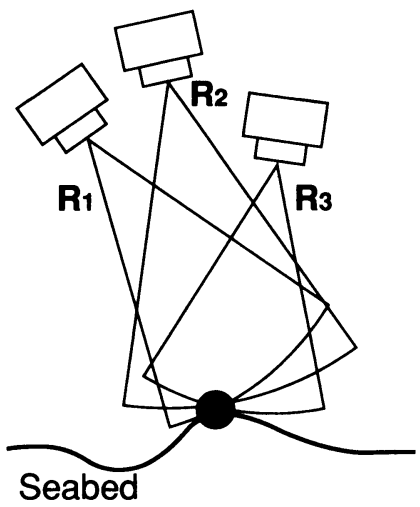

Fig. 4 Combining sensor readings from multiple positions

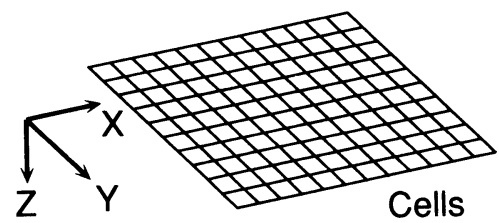

Fig. 5 Horizontal square cells in the target area

ゴリズムを提案する。

\section{2 地形図のための变数}

Fig. 5 に示すように水平面 $(x-y$ 平面) を等幅の矩形のセ ルに区切り，ここで梁さを定義する。オーバーハングが存 在しない前提では, 海底は各セルに於ける深さの集合とし て表現することができる。個々のセルについて， $Z_{c}, Z_{s}$ ，お よび $Z_{t}$ の 3 種類の深さを定義する (Fig. 6 参照)。 $Z_{t}$ は, 海 底の真の深度である。 $Z_{c}$ は, 本システムによって計算され る海底の推測深度である。 $Z_{s}$ は, 障害物が存在しないと推 定される最大の深度を表し, 以後安全限界深度と呼ぶ。潜 
水機は, たとえ情報不足のために推測深度 $Z_{c}$ が得られて いない場合にも， $Z_{s}$ まで降下する事ができる。

ひとつの測距デー夕は, 対応するいくつかのセルの, 海 底の深度の計測值 $z_{i}$ およびその重み $w_{i}$ に変換され, 障害 物の存在性に関する情報として蓄積される。同じ測距デー タから,その超音波が通過したことにより, 安全限界深度 の計測值 $z s_{j}$ が対応するセルに対して得られ, 障害物の不 存在性に関する情報として別に蓄積される。これらの数值 に基づいて, 次節以下に示すように $Z_{c}$ および $Z_{s}$ を決定す る (Fig. 7 参照)。

\section{3 障害物の存在性}

センサ前方の局所的な座標系を, Fig. 8 に示すように定 義する。

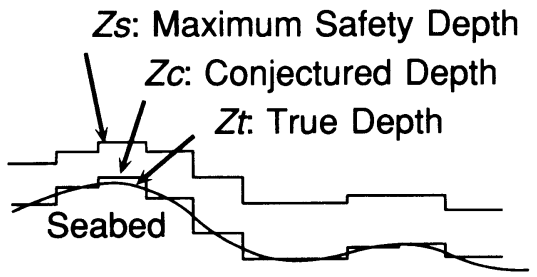

Fig. 6 Three definitions of depths

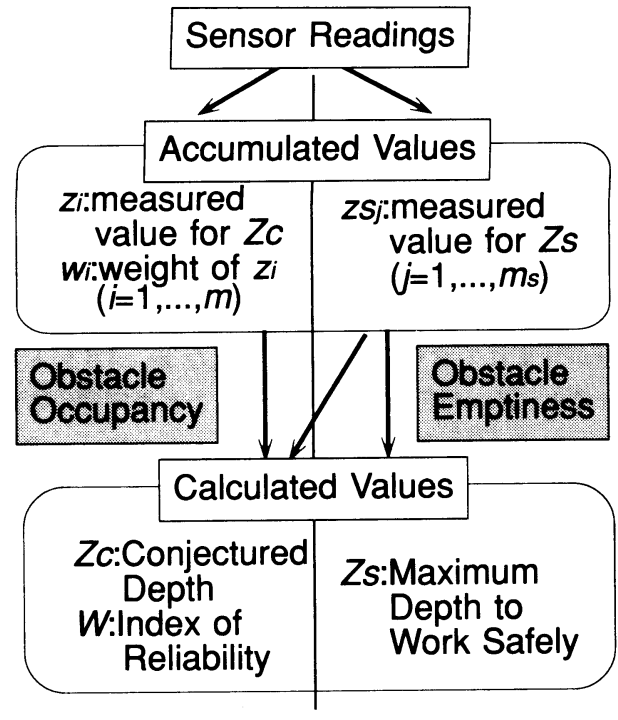

Fig. 7 Variables for each cell

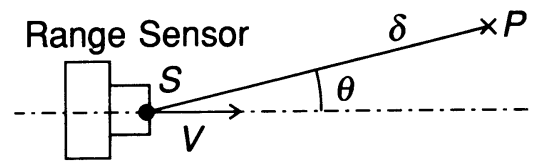

Fig. 8 Sensor coordinate system
$S:$ センサの位置

$P$ : センサ前方の任意の点の位置

$\delta:$ ベクト SP の長さ

$\theta:$ センサの主軸とベクトル SP のなす角

$R:$ 測距センサの計測値

測距センサのひとつの計測値に対して, センサ前方の空間 に超音波の反射点である確率(障害物の存在する確率)の密 度分布がひとつ得られる。確率密度分布 $f_{o}(\delta, \theta)$ はセンサ の性能に依存するが, $f_{o}(\delta, \theta)$ は指向角と測定精度に対応 する $\Omega$ と $\varepsilon$ という 2 つハハラメータによって, 次式のよう に簡略に表すことができる(Fig. 9 参照)。

$$
\begin{aligned}
& f_{o}(\delta, \theta)=\frac{1}{K} \cdot f_{o}^{r}(\delta) \cdot f_{o}^{a}(\theta), \\
& f_{o}^{r}(\delta)= \begin{cases}1-\left(\frac{\delta-R}{\varepsilon}\right)^{2} & \text { for } R-\varepsilon \leq \delta \leq R+\varepsilon \\
0 & \text { othewise }\end{cases} \\
& f_{o}^{a}(\theta)= \begin{cases}1-\frac{1-\cos \theta}{1-\cos (\Omega / 2)} & \text { for } 0 \leq \theta \leq \frac{\Omega}{2} \\
0 & \text { otherwise }\end{cases} \\
& K=\iiint_{D_{o}} f_{o}^{r}(\delta) \cdot f_{o}^{a}(\theta) d V .
\end{aligned}
$$

Fig. 10 のように, $f_{o}(\delta, \theta)$ がゼロでない空間 $D_{o}$ のうち セル $(x, y)$ に属する部分空間を $D_{o}(x, y)$ とする。セル $(x$, $y ）$ における海底の深度の候補 $z_{i}$ は, 部分空間 $D_{o}(x, y)$ に おける $f_{o}(\delta, \theta)$ の重心の深さとして定義する。 $z_{i}$ の重み $w_{i}$

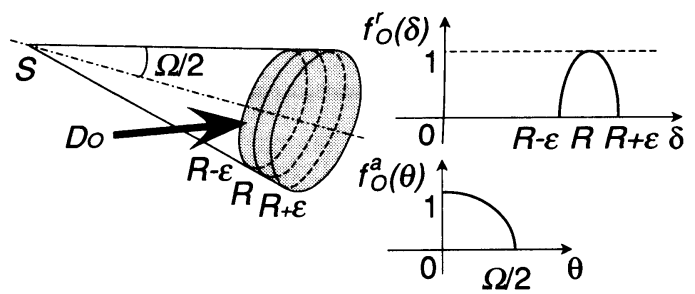

Fig. 9 Distribution of probability density to be the reflecting point

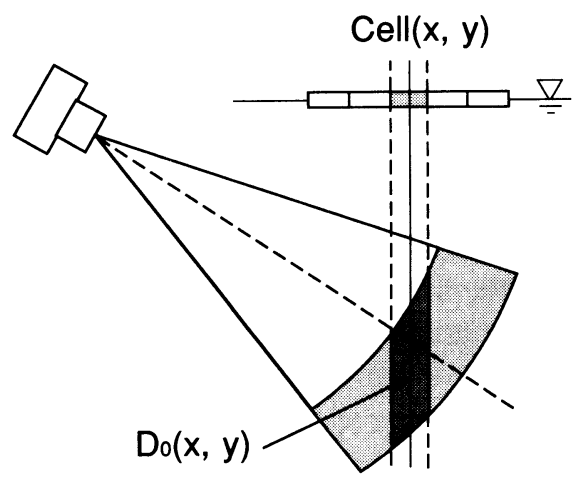

Fig. 10 Subspace $\mathrm{D}_{o}(x, y)$ 


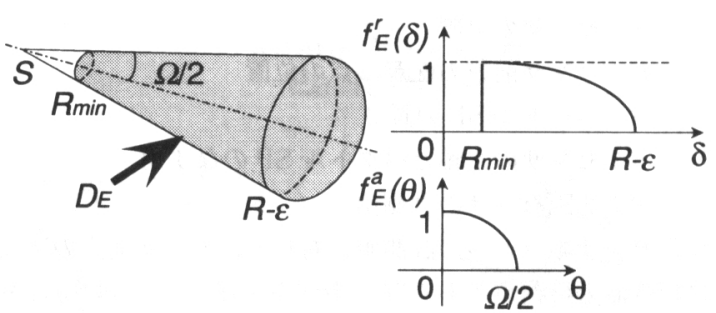

Fig. 11 Distribution of probability density to be the passing point

は $D_{o}(x, y)$ 内での $f_{o}(\delta, \theta)$ の積分值と定義する。すなわち

$$
\begin{aligned}
& z_{i}=\frac{1}{F} \iiint_{D_{o}(x, y)} z f_{o}(\delta, \theta) d V, \\
& F=\iiint_{D_{o}(x, y)} f_{o}(\delta, \theta) d V, \\
& w_{i}=\lambda F .
\end{aligned}
$$

ここで, $\lambda(0 \leq \lambda \leq 1)$ は, 海底における超音波の反射の特性 を表すパラメータである。

以上のように, ひとつの測距データに基づいて, いくつ かのセルの候補リストに $z_{i}$ および $w_{i}$ が一組づつ加えられ る。

\section{4 障害物の不存在性}

測距データによって，センサ前方の空間に超音波の通過 点である確率(障害物の存在しない確率)の密度分布も得ら れる。点 $(\delta, \theta)$ に扔ける確率密度 $f_{E}(\delta, \theta)$ は, 以下のよう に 3 つのパラメータ $\Omega, \varepsilon$ および $R_{\min }$ によって表す (Fig. 11 参照)。

$$
\begin{aligned}
& f_{E}(\delta, \theta)=f_{E}^{r}(\delta) \cdot f_{E}^{a}(\theta), \\
& f_{E}^{r}(\delta)= \begin{cases}1-\left(\frac{\delta-R_{\min }}{R-\varepsilon-R_{\min }}\right)^{2} & \text { for } R_{\min } \leq \delta \leq R-\varepsilon \\
0 & \text { otherwise }\end{cases} \\
& f_{E}^{a}(\theta)= \begin{cases}1-\frac{1-\cos \theta}{1-\cos (\Omega / 2)} & \text { for } 0 \leq \theta \leq \frac{\Omega}{2} \\
0 & \text { otherwise }\end{cases}
\end{aligned}
$$

関数值 $f_{E}(\delta, \theta)$ が閾值 $\eta$ より大である点 $(\delta, \theta)$ は, 障害 物が存在しないものとする。セル $(x, y)$ がこの障害物の存 在しない空間の真上にある場合，この空間の $(x, y)$ におけ る最大深度を $z s_{j}$ とし (Fig. 12 参照), セル $(x, y)$ のリス に加える。

\section{$2.5 \boldsymbol{Z}_{c}$ および $\boldsymbol{Z}_{s}$ の算出}

前 2 節で述べたように, 障害物の存在性・不存在性に関す る 2 種類の情報が, 各セルに対してそれぞれ独立に蓄積さ れる。これらの值は確率的なものであるため, 海底の深度 は両者を組み合わせて算出される。推測深度 $Z_{c}$ を $z_{i}$ の重 み付き相加平均值として次式で与える。

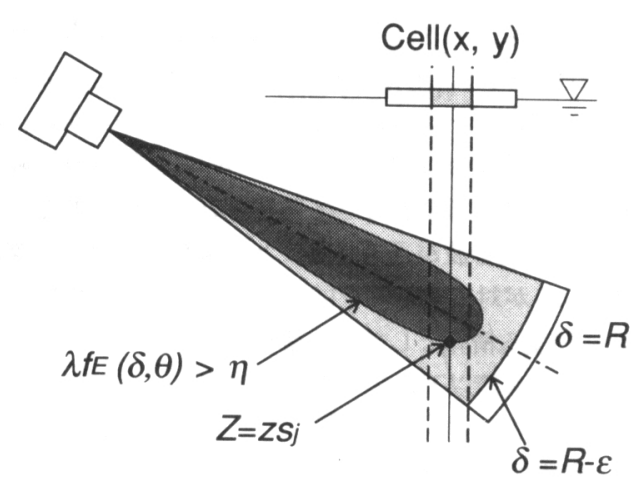

Fig. 12 Empty subspace

$$
\begin{aligned}
& Z_{c}=\left\{\begin{array}{l}
\frac{1}{W} \cdot \sum_{i=1}^{m} u_{i} w_{i} z_{i} \text { for } W>W_{0} \\
\text { “unknown" otherwise }
\end{array}\right. \\
& u_{i}=\sqrt{\frac{\operatorname{size}\left\{j \mid z s_{j}<z_{i}\right\}}{m_{s}},} \\
& W=\sum_{i=1}^{m} u_{i} w_{i},
\end{aligned}
$$

ここで $m$ および $m_{s}$ は， $Z_{c}$ および $Z_{s}$ のために計測されセ ル毎に蓄積されているデー夕 $z_{j}$ および $z s_{j}$ の個数である。 Eq. $(4 \mathrm{c})$ に示されるように, 各 $z_{i}$ の重みは Eq. (2 b) および (2 c) で定義される $w_{i}$ と, 障害物の不存在性を考慮するた めに Eq. (4 b)のように定義される $u_{i}$ の積とする。それら の積の和 $W$ は $Z_{c}$ の算出の際に用いられる情報の豊富さ を表し, 推測深度の信頼性の指標として利用できる。以後 $W$ を情報充足度と呼ぶ。 $W$ が閾値 $W_{0}$ 以下である場合, 算 出された $Z_{c}$ はシステムによって根拠がそしいと判断さ れ，そのセルの $Z_{c}$ を「末知」とする。

$z s_{j}$ が全て信頼に足りる值であるならば, 安全限界深度 $Z_{s}$ を $z s_{j}$ の最大值とすることができる。しかし $z s_{j}$ にも計 測誤差が含まれており，ひとたび過大な $z s_{j}$ がリストに登 録されると, $Z_{s}$ が訂正されなくなる。これを回避するため に, 各セルの $z s_{j}$ の平均値と標準偏差 $\sigma$ とを用い, 平均値 からの偏差が $3 \sigma$ 以内である $z s_{j}$ のみを有効とし, その中の 最大值を $Z_{s}$ とする。すなわち,

$$
\begin{aligned}
Z_{s} & =\max \left\{z s_{j} \mid z s_{j} \leq \overline{z s}+3 \sigma\right\}, \\
\overline{z s} & =\frac{1}{m_{s}} \sum_{j=1}^{m_{s}} z s_{j}, \\
\sigma & =\sqrt{\frac{1}{m_{s}}\left(\sum_{j=1}^{m_{s}}\left(z s_{j}-\overline{z s}\right)^{2}\right)}
\end{aligned}
$$

以上のように, 目標海域全体の地形図は, 全セルの $Z_{c}$, $W$ および $Z_{s}$ の組み合わせとして出来上がる。

\section{3. パスプラニング}

予め与えられたパスプランが, ある一定深度で格子状に 設定されているものを単純にトレースするようなものであ れば, それによって得られる超音波測距データを用いた地 
形図は，海山や海溝といった海底の起伏によって生じる陰 の部分をカバーする事ができない。また，計測値 $R$ が大き くなれば, 対応するセルの個々の $w_{i}$ は小さくなる。すなわ ち,正確な地形図を描くために充分な情報を得るためには, 潜水機はそれ自身の持つ地図に基づいて，場所に応じてな るべく海底面(障害物)の近くにまで接近する必要が生じ る。

本論で提案するパスプラニング用アルゴリズムは，2つ の段階により構成される。第 1 段階では, 目標海域全体の 大まかな情報を得るために, 潜水機は Fig. 13 に示すよう な予め決められたパスを一定深度で進む。この際, 潜水機 は目標海域全体の平均深度や最小深度といった粗い情報し か予め提供されていないとしている。目標海域が全体的に 浅い場合には，1筒所から計測できる面積が小さいので Fig. 13(a)のように密なパスを与える。この段階において 潜水機が活動する深度は, 障害物との衝突を避けるために 充分浅く設定される。第 1 段階終了時には，低精度の全体 的な地形図が描かれることになる。したがってこの程度の 地形図が予め与えられている場合は, 第 1 段階は省略する ことができる。
パスプランはホロノミックな潜水機ではどのようにでも とれるが, 航行型潜水機のような非ホロノミックなもので はその運動特性に合致するように決められなければならな い。本論では, 潜水機の運動性能は, 東京大学生産技術研 究所で 1992 年にソフトウエアの研究開発のために作られ たテストベッド自律型無人潜水機“Twin-Burger”3) の性能 を前提とし，ホロノミックな運動を前提とする。

\section{1 未知のソーンの探索}

第 2 段階では, Fig. 14 のように潜水機は以下に示す 4 つ の行動を繰り返し，地形図をより完全なものにしていく。

（1）目的地とそこへ至るパスの决定。

(2) 目的地の方位への定点回頭。

（3）決定されたパスのトレース。

(4) $180^{\circ}$ 定点回頭。

行動（1 ）のために, 目標海域を Fig. 15 のようにいくつ かのゾーンに区切る。潜水機の目的地は, $Z_{c}$ が末知である セルを最も多く含んでいるゾーンの中心に決定する。潜水 機のパスの水平面への写像は直線とし, パスの深さはその 時点の $Z_{s}$ 地図を用いて決定する。この決定方法は, 先に述 べたように潜水機の性能に依存する。

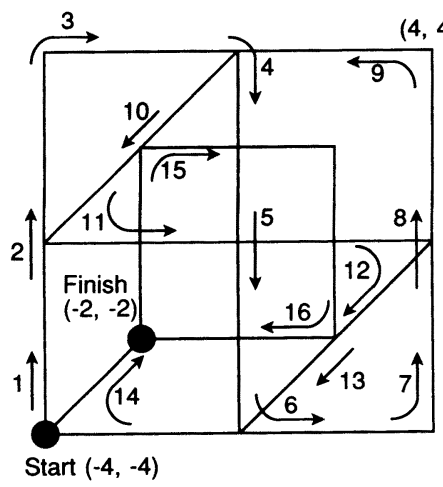

(a)

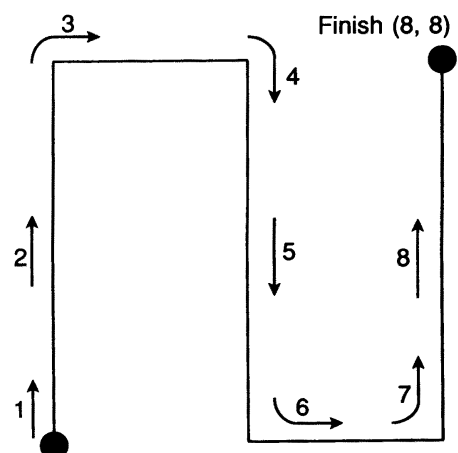

(b)

Fig. 13 Examples of path-plan in phase 1 to get a wide view

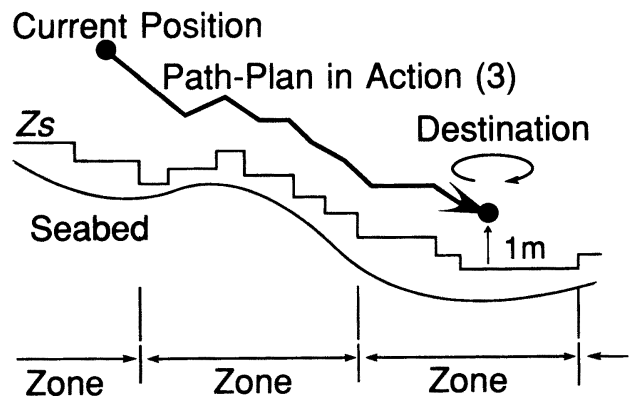

Fig. 14 Actions in phase 2

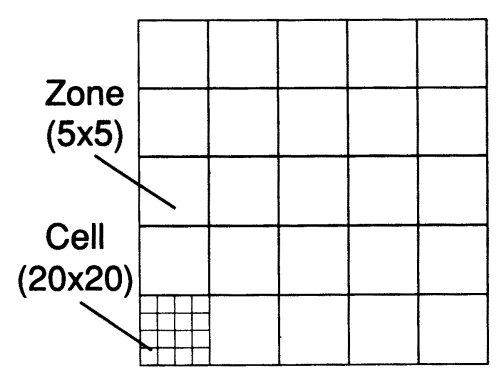

Fig. 15 Target area divided into zones 


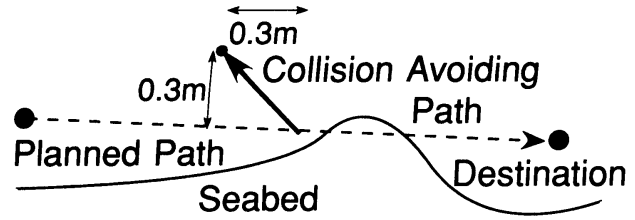

Fig. 16 Collision avoidance

行動（2），（3）および( 4 )で, 潜水機は一定時間毎に超 音波センサによる測距を行う。

\section{2 障害物回避}

前節で述べた行動 ( 3 ) の最中に, $Z_{s}$ 地図の不備などの理 由で，潜水機が予想以上に障害物に接近してしまう可能性 がある。したがって, 回避行動を規定しておく必要がある。 潜水機に搭載された測距センサのひとつがある閾値を下回 る距離を計測した場合には, システムは自動的に障害物回 避行動をとり, その後再び行動 (1) からやり直すとする (Fig. 16 参照)。

\section{4. システムの検証}

\section{1 地形図作成の実験}

地形図作成のアルゴリズムの有効性を検証するために, 東京大学船舶航海性能試験水槽 ${ }^{5}$ ( 水深 $2 \mathrm{~m}$ ) に打いて実験 を行った。使用した超音波センサは16個で, “TwinBurger”に搭載されているものと同型である。これらを Fig. 17 に示す向きに配置し, 試験水槽の $x-y$ 追跡電車上 の, 上下方向 ( $z$ 方向) に可動のターンテーブルに固定した。 実験中は, 直進時には $0.1 \mathrm{~m}$ 毎に, 回頭時には $5^{\circ}$ 毎に測距 した。第 1 段階で用いるために予め指定しておいたパスは, Fig. 13(a) の通りで, 深度は $0.55 \mathrm{~m}$ である。また, パラメ
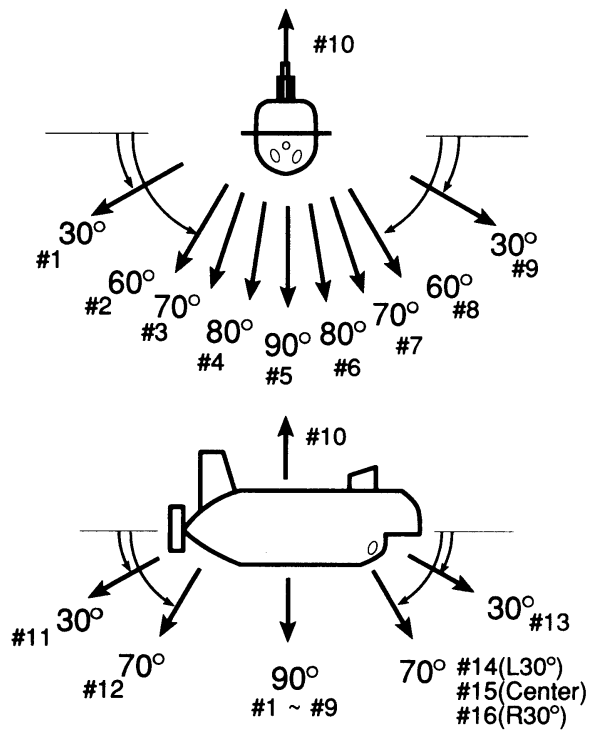

Fig. 17 Arrangement of 16 range sensors
一夕 $\Omega, \varepsilon, R_{\min }$ およびクは，それぞれ $20^{\circ}, 0.5 \mathrm{~m}, 0.3 \mathrm{~m}$, 0.05 である。

目標海域は $10 \mathrm{~m} \times 10 \mathrm{~m}$ で，その真の海底地形は Fig. 18 の等深度線図に示される。水槽内には, 円筒・直方体・ $45^{\circ}$ の坂を持つ山そして $30^{\circ}$ の坂を持つ 2 つの山の合計 5 個の 障害物が設置されている。目標海域は一辺 $0.1 \mathrm{~m}$ のセルに

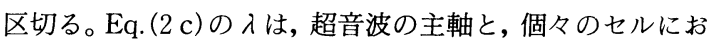
ける海底面の法線ベクトル $n$ とのなす角の余弦の 3 乗と した。ベクトル $n$ は, 注目しているセルの周囲の 8 つのセ ルの推測深度 $Z_{c}$ を基にして計算した。また，闘値 $W_{0}$ は 0.1 とした。

3.1 節の行動 (1) で決定される目的地の深さは, そこに 対応するセルの $Z_{s}$ より $1 \mathrm{~m}$ 浅くし, そのセルの $Z_{s}$ が得ら れていない場合には, 対応するゾーン内の全セルの既知の $Z_{s}$ の平均值で代用した。パスは現在位置と目的地とを直線 で結ぶ。また, 3.2 節の障害物回避行動は, 計測値のひとつ が $0.4 \mathrm{~m}$ 末満になったときに, 潜水機はその障害物とは反 対の方位に $0.3 \mathrm{~m}$ 平行移動しながら $0.3 \mathrm{~m}$ 浮上すること にした。

Fig. 19 は, 第 1 段階の 1,036 回を含む全 1,641 回の計測 が終了した後の地形図と潜水機の航跡である。 $Z_{c}$ の誤差の 平均值は $9 \mathrm{~cm}$ で, 全ての障害物の形状がはっきりと認識 されていることがわかる。

Fig. 20 は, 実験を通しての, $Z_{c}$ が得られたセルの個数と $Z_{s}$ が得られたセルの個数の移り変わりを表している。 $Z_{c}$ の個数の増加が緩やかであるのに対し， $Z_{s}$ の個数は急激に 増加する。探索行動の早期には多くのセルについて，例え $Z_{c}$ が決定できなくとも, 航行に必要な $Z_{s}$ を得ることがで きることが確認された。このように, 3.1 節の行動 ( 1 )でパ スの深度を決定するに当たり， $Z_{c}$ を用いる代わりに $Z_{s}$ を

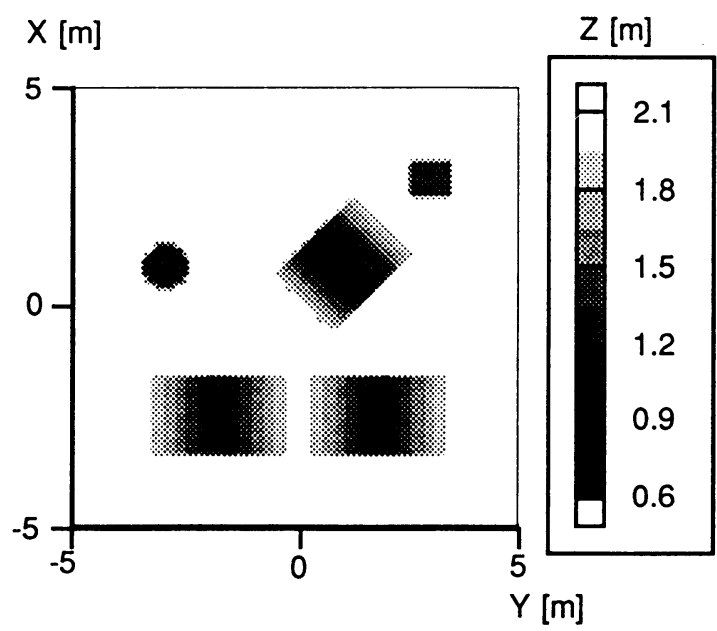

Fig. $18 Z_{t}$ (true depth) for the experiment ; 5 obstacles on the floor of the pool. 


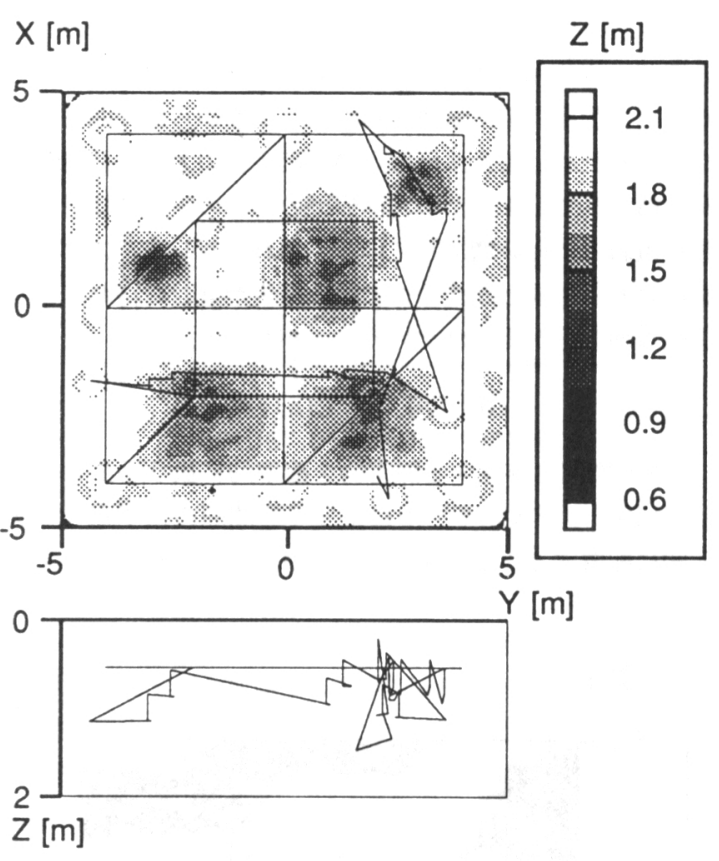

Fig. 19 Zc (conjectured depth) and trajectory after 1641 measurements

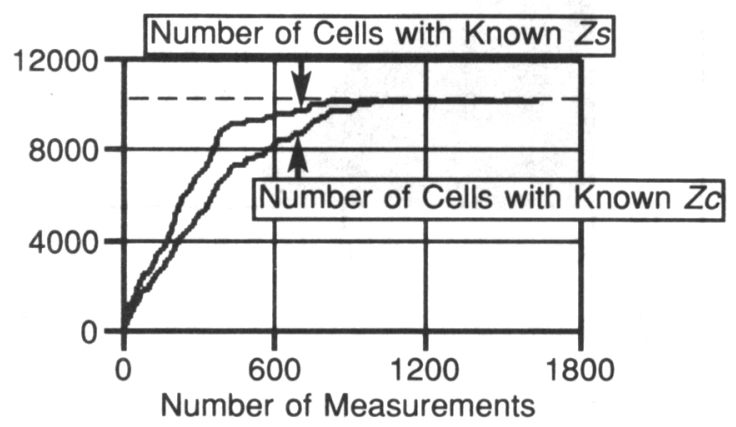

Fig. 20 Results of the experiment

利用したことの妥当性が示された。

Fig. 21 は， $W_{0}=0$ としたときの $W$ と $Z_{c}$ の誤差との関 係を表している。Wが増加するに従い誤差が減少するの で, $Z_{c}$ の誤差は $W$ によって評価することができる。 $W_{0}$ が より大きな值に設定されれば, $Z_{c}$ の得られるセルの個数は より小さくなるものの, $Z_{c}$ の誤差は全体的に減少に向か う。

\section{2 パスプラニングのシミュレーション}

本論の提案するパスプラニング用アルゴリズムに基づい て,より複雑な海底地形を舞台にしたシミュレーションを 行った。この結果を, 予め与えられた単純なパスプランに 沿って, 同じ地形を探索させた場合の結果と比較した。シ ミュレーションのプログラムは, 仮想的な海中環境で複数

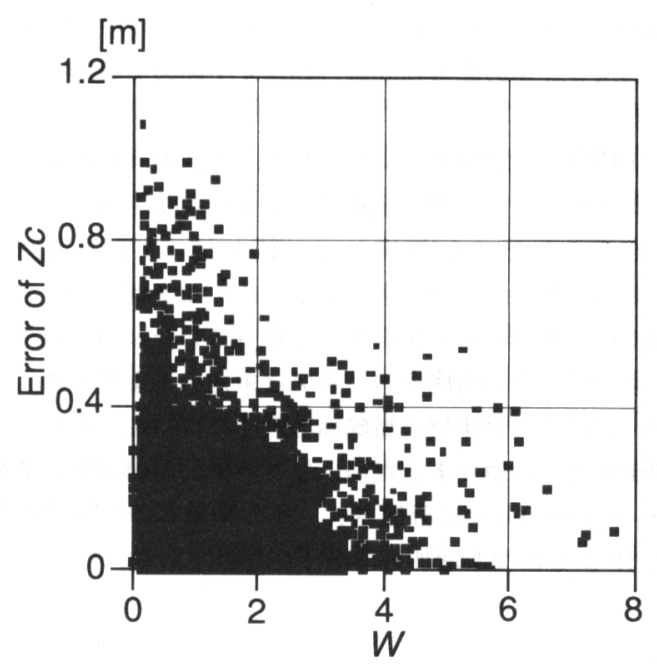

Fig. 21 Relation between $W$ and error of $Z_{c}$

の潜水機の行動の研究を行うために著者らの研究室で開発 された MVS(Multi-Vehicle Simulator) ${ }^{4)}$ を基にしてい る。

目標海域は $20 \mathrm{~m} \times 20 \mathrm{~m}$ で, その海底地形の等深度線図 は Fig. 22 の通りである。これは海洋科学技術センター提 供による八丈凹地の実測地図を, 縮尺を変更して用いてい る。セルは一辺 $0.2 \mathrm{~m}$ の正方形で, 第 1 段階のために与え たパスはFig. 13(b)に示してある。パラメータ $\Omega, \varepsilon, R_{\min }$ および 時と同様に, 潜水機は直進時に $0.1 \mathrm{~m}$ 毎に, 回頭時に $5^{\circ}$ 毎 に測距データを得る。また，閾值 $W_{0}$ は 0.1 とした。

3.1 節の行動 ( 1$)$ では, 一連の $(x, y)$ 座標を各時間ステ ップ毎に決定した後, 個々の $(x, y)$ に対応するセルの $Z_{s}$ よりも $1 \mathrm{~m}$ 浅い深度にパスの深度を決定する。 $Z_{s}$ が末知で

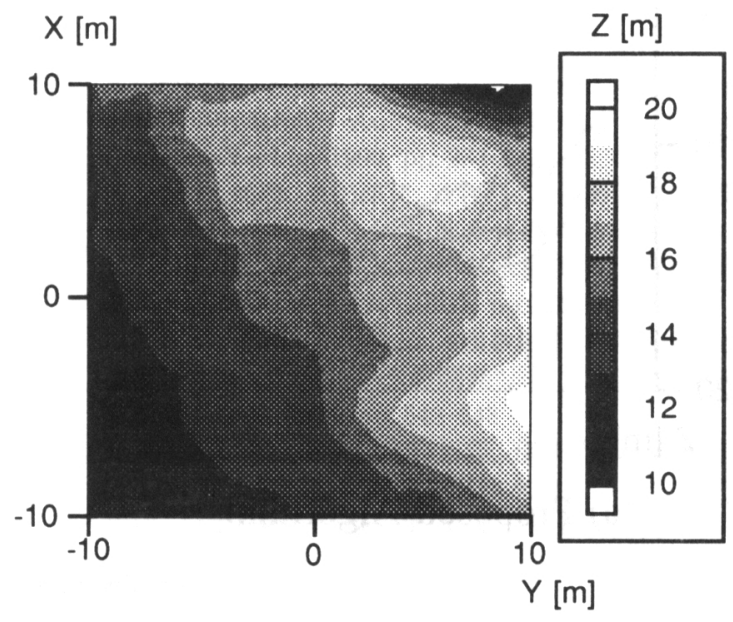

Fig. $22 Z_{t}$ (true depth) defined for the simulations 
ある場合には前の時間ステップの $(x, y)$ の $Z_{s}$ で代用す る。また, 3.2 節の障害物回避行動は 4.1 節の実験時と同様 にした。

第 1 段階の 748 回の計測を含む 3,000 回の計測の結果得 られた地形図とその間の航跡を Fig. 23(a ) に示す。また, 予め与えられたパス (深度 $1 \mathrm{~m}$ 一定)に沿って同じ海底地 形を計測し得られた地形図を Fig. 23（b ）に示す。(a )の地 形図では，末知のセルがほとんど残っていないが，(b)の 地形図では, 深い海底面のエリアは未知のままである。こ れは，（b ）では潜水機が海底面の近くに行くことがなく， 測距値が大きな值であるため，ひとつの計測值に対して重 み $w_{i}$ が多数のセルに分散され，その結果このエリアのセ ルの $W$ がなかなか増加しなかったためである。
これら 2 つのケースのシミュレーションを通しての, $Z_{c}$ の誤差の平均值の推移を Fig. 24 に示す。予めパスを与え たケースでは, 常に海底から離れた深度から広範囲を見渡 しているため, 超音波反射点の不確定性の大きな計測情報 が蓄積されてしまうため, 地形図の䛊差の平均值は計測回 数を重ねるに従い増加している。それに対してパスプラン を自動的に生成したケースでは，探索が進むにつれてより 正確な地形図が得られていくことがわかる。

5. 考

察

3 次元空間に存在する障害物を確率的に扱う手法として は, Elfes の 2 次元モデルに倣って等間隔の格子点を 3 次 元的に配置する手法がまず考えられるが，各格子点の障害
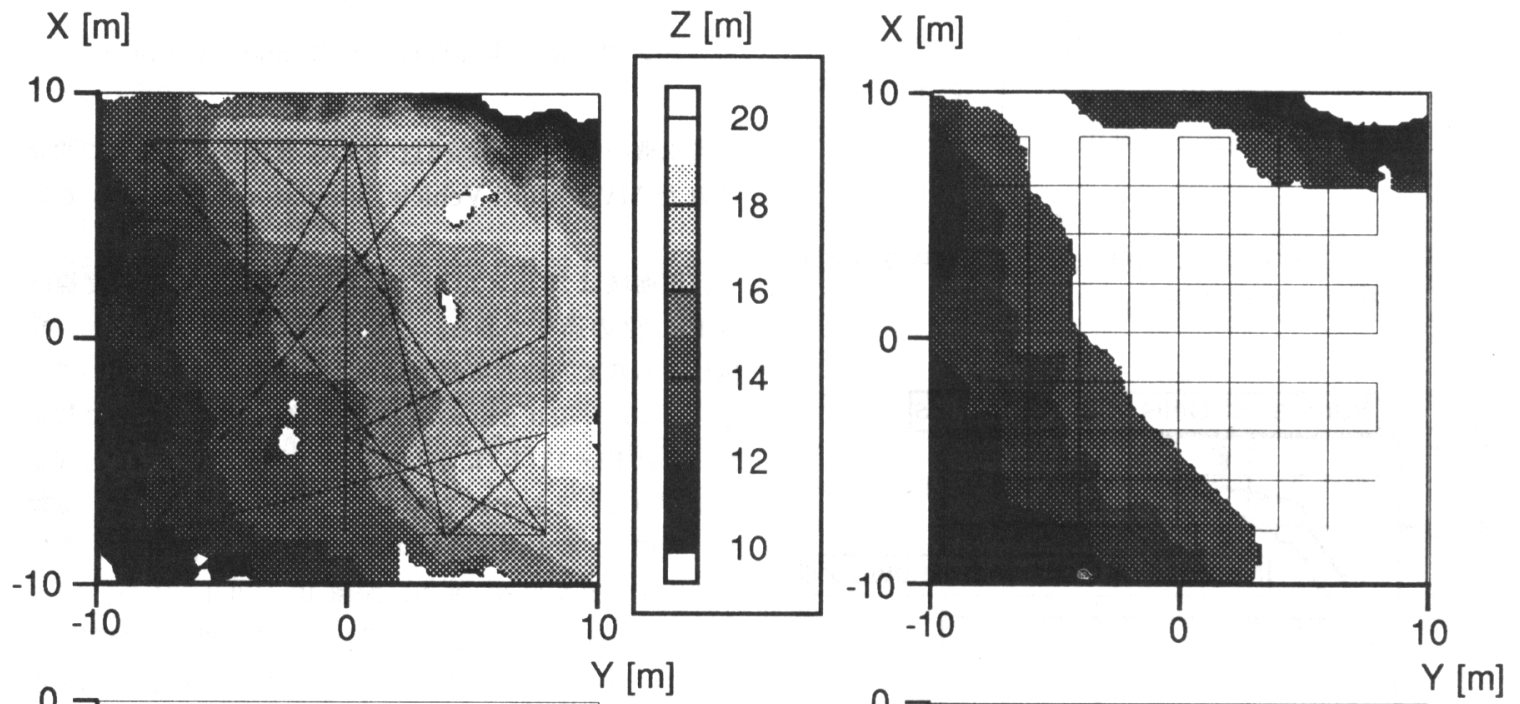

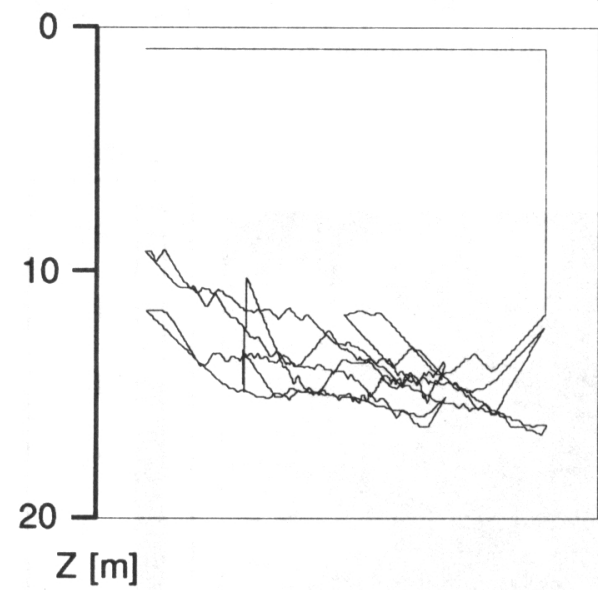

(a) Proposed Algorithm

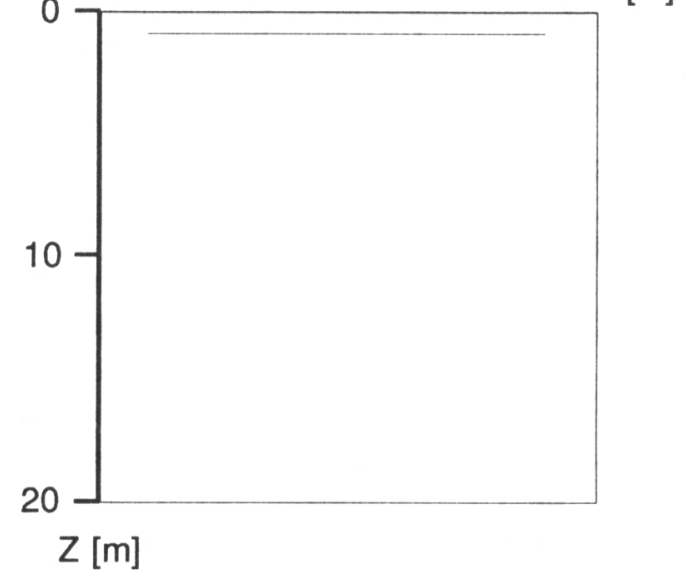

(b) Prescribed Path-Plan

Fig. $23 Z_{c}$ (conjectured depth) and trajectory after simulated 3000 measurements; White areas are "Unknown". 


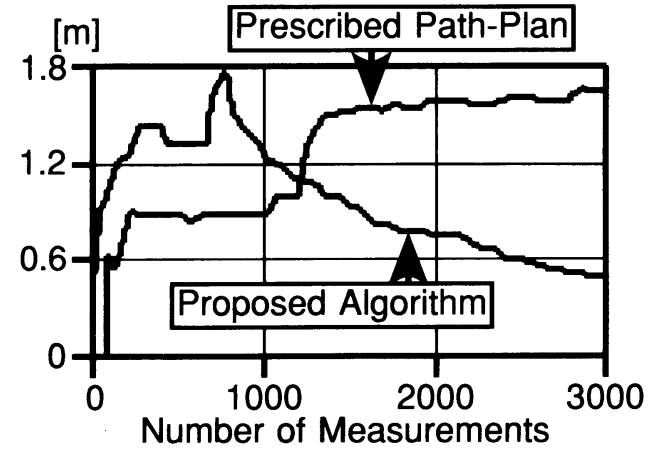

Fig. 24 Mean error of $Z_{c}$ in simulations

物存在・不存在を判定して寄せ集めただけでは深度を離散 的に扱うことになり, 高精度を望むとその 3 乗のオーダー の密度で格子点を配置する必要がある。それに対して, 本 論で提案する地形図のモデルは, 水平面内に配置したセル に変数 $z_{i}$ および $z s_{j}$ を定義することにより, 深さ情報を連 続值として扱うことができ, 実システムに組み込む際にメ モリーの容量の節約や計算の組み合わせの数の抑制などの 点で有利であり,より現実的である。

$Z_{c}$ の算出に用いられる $w_{i}$ は, セルによってその分布が 異なると予想される。 $z_{i}$ を $w_{i}$ で重み付き平均するため, 值 の小さい $w_{i}$ ばかりが多数存在する場合は, 值の大きい少 数の $w_{i}$ の場合に比べて, $W>W_{0}$ であっても $Z_{c}$ が正確で ない可能性がある。したがって, 今後の課題として $Z_{c}$ の算 出には $w_{i}$ の分布を考慮することが挙げられる。いずれに せよ, デー夕集合 $\left\{z_{i}, w_{i}\right\}$ を基にした $Z_{c}$ の算出法は, 複数 の計測デー夕を組み合わせるという点で, より正確な地形 図を描くために有効であると考えられる。

本システムは, $W \leq W_{0}$ ならば $Z_{c}$ を「末知」と判断する ことにより，根拠の乏しい推測を避けている。それは，同 じ場所で計測を繰り返すとそれに対応するセルの $W$ ばか りが増加してしまい得られる $Z_{c}$ が正確でない可能性があ るものの, それに留意すれば $W$ は対応するセルに関して 得られている情報量の尺度と位置づけられるからである。 より正確な地形図が必要であれば， $W_{0}$ をより大きな值に 設定することにより実現できる。

本論で提案するパスプラン用のアルゴリズムでは, $Z_{s}$ を 利用して潜水機の安全性に配慮している。 $Z_{s}$ の決定には Fig. 12 のもも影響を与える。 テムが下す判断は安全側に移るので, $\eta$ を適切に設定する ことにより探索活動の性質や潜水機の運動特性などに応じ たパスプランを作成できる。

また, 提案のアルゴりズムは, ゾーンという固定された セルの集合について $Z_{c}$ が末知のセルの個数を比較し, そ
れが最大のゾーンへ探索に向かうというものである。これ に対して, $Z_{c}$ が末知で隣接しているセルをひとつのゾーン とする手法や，近くのゾーンから順に探索するなどのバリ エーションも考えられる。提案する手法では, 計算量が少 ないので実システムに組み込みやすいという利点がある。

\section{6. 結言}

推測深度 $Z_{c}$, 情報充足度 $W$ および安全限界深度 $Z_{s}$ と いう值を導入することにより，潜水機の超音波測距センサ を用いて海底の複雑な地形を読みとり地形図化する手法を 提案した。試験水槽における実験により, その手法の有効 性を示した。

$Z_{s}$ や $W$ という情報を利用することにより, 予め潜水機 に与えておく形式のパスよりも柔軟性の高いパスプランを 生成するためのアルゴリズムを提案した。ワークステーシ ヨン上のシミュレーションにより，格子状の単純なパスを 用いた場合に比べて，提案のアルゴリズムを用いればより 優れた地形図を得られることを示した。

本論の提案するこれらのアルゴリズムは, ROV (Remotely Operated Vehicle)や, AUV(Autonomous Underwater Vehicle), そして有人潜水船などの, 様々な 潜水機の活動に応用することができる。

\section{謝辞}

超音波センサを製作して頂いた海洋電子の村上英幸氏， 実験に際し御援助頂いた東京大学生産技術研究所の能勢義 昭助手, 鈴木文博氏, 坂巻隆氏, 東京大学船舶航海性能試 験水槽の石井裕司氏, ならびに八丈凹地の地形データを提 供して頂いた海洋科学技術センターの松本剛氏に深く感謝 致します。

\section{参 考 文 献}

1) A. Elfes: "Using Occupancy Grids for Mobile Robot Perception and Navigation", Computer, 22, 6, 1989, pp. $46-57$

2) A. Elfes: : "Sonar-Based Real-World Mapping and Navigation", Autonomous Robot Vehicles, Springer-Verlag, 1990, pp. 233-249

3）藤井輝夫, 浦環, 黑田洋司, 荒牧浩二, 能勢義昭, 千葉 裕之：“海中ロボットの知能化に関する研究(その 1 : 汎用テストベッドの開発と水槽実験)”, 日本造 船学会論文集, Vol. 174(1993), pp.9 03-916

4）黑田洋司, 浦環, 荒牧浩二: “複数海中ロボット対応 型仮想環境シミュレータの開発”, 第 12 回海洋工学 シンポジウム, 1994, pp. 543-548

5）元良誠三, 小山健夫, 藤野正隆, 伊田力, 小柳雅志 郎: “東京大学船舶航海性能試験水槽について(第 1 報)”, 日本造船学会論文集, Vol. 128(1970), pp. 213219 